\title{
The Effect of Using Six-hat Strategy on Developing Creative Thinking Skills among Fourth Grade Students
}

\section{Mohamed Hammouda}

Master of Arts in English Language - Translation

An English teacher at the Ministry of Education,

Khalil Ali Abu Jarad

Master of Educational Psychology

lecturer at Al-Quds Open University

\section{Abstract;}

his study aims at developing creative
thinking skills using six-hat strategy and
revealing the relations between developing creative thinking skills and six-hat strategy for primary school students at fourth grade. To achieve the aims, the researchers examine the following hypothesis:There are statistically significant differences at the level (0.05) between the average scores of students of the experimental and control groups in the post-application of the creative thinking test in favor of the experimental group.There are statistically significant differences at the level (0.05) between the average scores of the experimental group students in the pre and post application in favor of post-application in the post-creative thinking test in favor of post-application.There are statistically significant differences at the level (0.05) between the average scores of students of the experimental group in the pre and post application in the skill of fluency in favor of post application.There are statistically significant differences at the level (0.05) between the average scores of the experimental group students in the pre and post application in the skill of originality in favor of post application.There are statistically significant differences at the level (0.05) between the average scores of the experimental group students in the pre and post application in the skill of flexibility in favor of the post application. There are statistically significant differences at the level (0.05) between the average scores of the experimental group students in the pre and post application in self confidence level in favor of the post application.They follow the 
experimental approach in which they divide a sample of 80 students into two groups: 40 in experimental and 40 in controlled groups. They carry out a pretest and post test and between them, they give 13 lectures. The results show that the five hypotheses are confirmed. Finally, the researchers recommend encouraging teachers to employ and use De Bono technique in all academic subjects that help develop creative thinking and its skills among students of the primary stage.

Keywords: Six-hat Strategy, Creative Thinking Skills

\section{Introduction}

Our life nowadays witness a rapid change, so we are in a need to revise ourselves and change our way of thinking. This will qualify us to deal with the future sciences and creativity. This also forces us to think seriously in developing our thinking due to its high rage among sciences generally because thinking's job is to find out solutions for everything that humans face practical and theoretical problems, and to bring them in a level of progress and development. (Habsh, 2005: 15). Zayton (1987: 5) points that "it has become the most important educational aims which societies seek to fulfill to its individuals". So, it is necessary for encouraging it inside schools as referred by (Abd ElHady and 'ead, 2009: 115). According to Starko (2005), creative thinking is a distinct task in the field of stimulating the student's motivation to learn. In addition, it is regarded as the most prestigious type of thinking. Because it is a human trait, this makes it more complex and wide. Thus, we find confusion in putting a specific definition for creativity. Sometimes, researchers focus on the characteristics of the creative person. Other times, they focus on the creative product itself. 
The most skills for creative thinking which are necessary for happening creativity phenomenon are the followings: (Sa'ada, 2003: 29), ( Saed, 2010: 34)

- Fluency: it is the first step toward increasing the possibility of happening creativity phenomenon. It means the multiplicity of ideas which the teacher can come up with. Also, the creative ideas are characterized with its suitability to the real environment. Thus, whenever the learner is able to create greater number of ideas or answers during a specific time period, $\mathrm{s} /$ he is more fluent. Also, fluency includes the following types: verbal fluency association fluency - fluency of ideas - fluency of forms.

- Flexibility: it is the skill which can be used in creating various forms or patterns of thinking. It sharpens the ability of transforming these patterns and change the direction of thinking. Thus, we move from the ordinary thinking to respond to the reactions and recognition in different ways. Last, flexibility has different types, such as automatic flexibility adaptive flexibility - redefinition flexibility.

- Originality: it is the skill used to think of unique ways and responses. This importance of teaching this skill is encouraging the students to think creatively which help them work hard to research for new ideas. If the student is able to understand and recognize things deeply, thus s/he is able to find new ideas.

Due to the fact that creative thinking is one of the most complex educational outcomes which has become an educational aim, teaching process seeks to fuliful it in 
order to enable the learners to go hand in hand with real life which has become very complex (Al-Naqa, 2006: 18). One of the manifestations of interest in creative thinking has held many conferences, including:

- The seventh international conference for thinking, June, 1997, held in Singapore in the first till sixth of June, 1997.

- The twelve's scientific conference " curricula of education and developing thinking" at Ain Shams University from 25-26 July 2000.

- The third scientific conference "teaching and learning mathematics and developing creativity", held in 8-9th of October, 2003 at Dar Teafa- Ain Shams university.

- The fourth scientific Arab talented and outstanding students in Jordan, 2003. The most important aims of this conference is to direct the attentions towards fields of talent and creativity.

- These confidences stress the followings:

- Preparing students educationally in a way which is characterized by creative thinking in the light of continuous scientific developments.

- Stressing the teachers' roles as a basic base in developing students' creative thinking

- Developing the creative abilities of the students through targeted programs and various teaching strategies.

Because of the importance of developing learners' thinking, researchers have developed a large number of programs and strategies aiming at developing thinking skills for all levels of education. Among these programs is what Edward De-Bono has proposed. During many 
years, he has proposed many programs which are widely spread in Arab and foreign worlds about developing thinking skills. One of the most of these strategies is six hat strategy. Actually, De-Bono is considered one of the pioneers of thinking, especially creative thinking.

Six hat strategy is considered one of the most important methods of developing creativity and improving creative thinking. It gives thinking process more time and efforts since it links between creative thinking as a type of thinking for humans with their thinking and mental ways of dealing with what happens. The key of six hats is to direct the student to think in a certain way. Then, it forces him to change his thinking into another way, such as changing his thinking to think in the green hat. The aim of all these things is to provoke the students' souls and be able to see the things from different angles. Thus, the teacher will be able to teach the students the thinking skills throughout six-hat game. When they know the meaning of every hat color, this will motivate them to think deeply in every type (Sternberi, 2005: 26).

De-Bono (2001: 263) thinks that every hat has a meaning, and the student can identify the type of thinking based on the color:

- White hat: stands for the given information and data

- Red hat: stands for emotions and feelings without any reasonable justifications.

- Yellow hat: stands for optimism, referring to the positive thinking, and highlighting the positive side. 
- Black hat: stands for fear and pessimism, criticism, and thinking of the wrong decisions, blocks, and problems.

- Green hat: stands for the creative thinking

- Blue hat: stands for the overall thinking which called the general view thinking.

Batchelor (2014: 13) stresses that the color helps students mediate while thinking, and know the differences between ways of thinking. That is very important for the various educational situations. This facilitates thinking patterns.

The researchers have carried out a survey in conducting a test based on creative thinking in sociology. The sample included is 40 students, studying at the fourth grade at Beuit Lahya primary school (B) in the Northern Directorate of Education, Gaza. The researchers have prepared the test based on the tests organized to examine creative thinking in terms of the form and the content of the test items. it examines the three creative abilities: fluency, flexibility, and originality in English language material. The results show that $50 \%$ of the students use creative thinking.

\section{The study problem}

Based on the results of the previous studies, research, and the survey, the primary students' usage of the creative thinking skills is low im Palestine. To overcome this problem, this research seeks to answer the following questions : Is six- hat strategy effective in teaching English language to develop creative thinking skills for the fourth grade students? 
From this question, a sub-question emerges: is six-hat strategy effective in teaching English language to develop some of the creative thinking skills for the primary grade students?

\section{Study hypotheses}

- There are statistically significant differences at the level (0.05) between the average scores of students of the experimental and control groups in the postapplication of the creative thinking test in favor of the experimental group.

- There are statistically significant differences at the level (0.05) between the average scores of the experimental group students in the pre and post application in favor of post-application in the postcreative thinking test in favor of post-application.

- There are statistically significant differences at the level (0.05) between the average scores of students of the experimental group in the pre and post application in the skill of fluency in favor of post application.

- There are statistically significant differences at the level (0.05) between the average scores of the experimental group students in the pre and post application in the skill of originality in favor of post application.

- There are statistically significant differences at the level (0.05) between the average scores of the experimental group students in the pre and post application in the skill of flexibility in favor of the post application. 
- There are statistically significant differences at the level (0.05) between the average scores of the experimental group students in the pre and post application in self confidence level in favor of the post application.

\section{The study aims}

This study aims at achieving the followings:

- Developing creative thinking skills using six-hat strategy

- Discovering the link between creative thinking skills and six-hat strategy for the fourth grade students in English language.

\section{The importance of the study}

This study is important due to its huge possible contributions in the followings:

- Developing some of creative thinking skills using sixhat strategy for the fourth grade students in English language

- Helping the students to recognize creative thinking skills, thus, developing them among the students

- Attracting the teachers' attention to use six-hat strategy to develop creative thinking skills

- The results of this study may be a starting point for wider studies which rise the development level of the curriculum at the Palestinian schools.

\section{Study limitations}

- The sample is fourth grade students studying at Beuit lahya primary school at northern directorate education, Gaza 
- Preparing a suggested version to include creative thinking skills in teaching English language and choosing a unit for application.

- Three of creative thinking skills mainly: fluency, flexibility, and originality.

\section{Study definitions}

\section{Six-hat strategy:}

is a strategy for developing thinking, proposed by Edward De-Bono. It is based on the assumption that wide thinking includes big hat for thinking which is divided into six hats with six different colors. By using these hats, the student put the one which s/he thinks it is suitable in order to play the suitable role. So, every student has a goal whenever wearing a specific hat (De Bono, 2000).

\section{Procedural definition:}

is a modern technique, proposed by the British doctor with Maltase origin Edward Bono to facilitate thinking process. He divides thinking into six forms, considering every form as a hat worn or taken off by a person based on his/ her way of thinking during that moment. The person moves with his/her thinking based on the situation $\mathrm{s} / \mathrm{he}$ is facing. Bono gives every hat a specific color to distinguish it easily.

Creative thinking: is creating original ideas or new products (Zaytoom, 2003: 62).

\section{Procedural definition:}

is a sophisticated skill that leads to a purposeful mental activity and production guided by a strong desire for investigation and research to generate original and 
unique ideas and constructive solutions by basic stage students and measured by the creative thinking test prepared for that.

\section{Creative thinking skills}

- fluency: is the ability to quickly produce the largest possible number of ideas and give new solutions, around a specific idea in a specific period of time, according to conditions determined by the situation.

- Flexibility: means changing the state of mind by changing the situation. It is the ability to generate diverse and different ideas that guide thinking according to the requirements of the new situation and is the opposite of the process of intellectual rigidity

- Originality: is the ability to generate new ideas. It is the ability to produce ideas characterized by novelty, originality and creativity. These ideas are extraordinary and unfamiliar.

\section{First: theoretical framework}

\section{Creative thinking and its skills}

Thinking is considered as a major teaching aim in modern education. Educators believe that helping students acquire thinking skills and using and applying them is a major teaching goal for modern education (Zayton, 2001: 50).

\section{Creative thinking definition}

Creative thinking is one of the most sophisticated forms of thinking. It provokes the students' desire to learn and generate new information and unique ideas to find a solution or to explain a specific phenomenon. 
Also, creative thinking is one of thinking forms which provides the society with the needed ideas in order to move the society form imitation stage into modernization (Rashtya, 2002: 57).

According to Al-Khateeb (1995:195), creative thinking is divided into the followings:

- Direct creative thinking: it includes direct thinking of the problems and their solutions in the book. It also includes remembering, distinguishing, and defining questions, and summarizing, explaining, elaborating, translating, comparing, and changing form one state into another.

- Indirect creative thinking: it is creative thinking which provokes mental abilities by introducing many questions in problems form. These questions do not have a direct solution in the book, but they need to be inferred and clarify the relations between things, imagination, and experimentation.

\section{Creative thinking trends}

There are many trends dealt with creative thinking in terms of analysis and explanation. The most famous of those are (Sa'ada, 2014: 261- 262) and Al-Soror, 2002: 64- 65) as follows:

- associative trend: was led by Thorndike who pointed out that creative thinking is associative thinking that results from the relationship between stimulus and response. The value of creative thinking is determined by the extent of the type of bond. if it is strong, it will be repeated and strengthened, but if it is weak, it will disappear and fade. Thorndike's idea may later be adopted by Mednick and Maltzman. 
- Behavioral trend: is adopted by skinner, who thinks that creative thinking is the kind of thinking that gets reinforced or rewarded, which leads to the possibility of its continuation. However, if it does not gain the required reinforcement, it becomes an unwanted thinking and starts to diminish and then disappear. Skinner's view is later endorsed by educator Crobley.

- Gestalt trend (clairvoyance): The interpretation of creativity is adopted by the scientist Fertimr, who assumes that creative thinking is clairvoyant thinking and intuitive thinking. The creator's mind is active in an unusual way, and the situation is treated with new treatment, then he had known it before.

- Analytical trend: Copah assumes that creativity requires temporary freedom for pre-awareness and feeling because subconscious part stimulates the mind and urges it to think. He justifies all of this by stating that the free playing of conceptual processes precedes the words that have the minimum level of communication.

- Humanistic trend: Rogers says that everyone is born creative and must have educational conditions, experiences and attitudes in order to reach the maximum possible growth and lead to the best expected performance. In addition, Barbara Clark assumes that optimal learning is the kind of learning that makes the student reaching the state of creative thinking.

- Cognitive trend: Taylor and Gitzells believe that creative thinking is a mental process that is proceeding based on a series of processes through which the subject is addressed and linked to a large number of experiences. These experiences are stored 
in the learner's cognitive structure, and works to introduce them within the self and then integrating them with the cognitive structure. Finally, they reach new and original solutions.

\section{Creative thinking characteristics}

Creative thinking is characterized by many characteristics which are clarified by Ali (1999: 22), Naf' (2008: 3), Jawad, (2010: 208), and Katmany and others (2008: 30-31) as follows:

- It is not bound by logic

- We can get correct results from wrong introductions

- Divergent thinking

- It adds, renews, and changes

- Difficult to predict its results

- Original and rare to be existed. Rarely repeated in different courses.

- Flexible, independent, and self-controlled

- Reflect different interests

- Develop discovering and exploration skills

- It includes higher thinking skills

\section{The importance of developing creative thinking}

Creative thinking has a distinctive importance aomg people. these importance is clarified by (Ali, 2011: 34), Al-Khader and Syam (2013: 51), Al-Deep (2005-34), AlMoshref (2005-78), Al-Kahtani (2000: 40) and AlHosany (2006:3) as follows:

- Creativity leads to improvement and development since it is considered a strong factor to provoke enthusiasm. Creative thinking improves and develops performance. 
- Creative thinking leads to avoid problems before happening. It gives us the opportunity to widely discover the various situations.

- Creativity appears as a requirement which the educational institutions need for in the 21 century in order to achieve the highest levels of effectiveness. It also helps people adapt the surrounding changes.

- We need creative thinking to put strategies to achieve the goals using the best tools with the lowest amounts of money.

- Creativity is an effective tool for change. It also is considered one of ingredients of completing the change process and dealing with problems positively.

- Creativity achieves educational aims because education is the process of creating links between the person and his/her environment. It aims at building a person who has values, morals. This never achieves through minds that depend on traditional thinking without any kind of creativity. As the students are the main stone in the society, we must work hard to sharpen their creative thinking skills.

\section{Levels of creative thinking}

Creative thanking differs among people based on the deepness. Taylor (1959) discovers five levels of creativity as mentioned in Al-Khader (2014: 118), AlMoflh (2006: 37), Al-Madhon (2012: 31-32) and 'bad and Afana (2003: 50) as follows:

- Creativity at the expressive level: all the following levels are based on the expressive level. It is represented in the automatic and spontaneous drawings for children. 
- productive creativity level: the tendency to improve the style of performance appears under specific rules, such as developing a musical instrument or developing a machine that facilitates agricultural work.

- inventive (innovative) creativity level: The most important characteristics of it is invention and discovery, such as the ability to use materials in a new and developed way without making a new and developed contribution to knowledge, principles or theories, such as the inventions of each of Addisomadconi.

- regenerative creativity level: It requires an amendment to the general principles governing a field in science, literature, or art, such as the additions provided by Warford on a model in the atom.

- The emerged level of creativity (the new): This type requires original and varied thinking in the ideas presented.

\section{Creative thinking skills}

\section{Fluency}

- Definition: it is the mental skill that is used to generate the thinking which goes freely in the light of many ideas connected (Sa'ada, 2014: 275).

- The importance of developing fluency skill: fluency has a great importance, clarified by Al-Jamal (2005: 50), Al-Katmany (2001: 198), Torrance (1995: 30), Omar (2012: 17-20). Its importance emerges from the fact that it helps people move easily from the long-term memory to the related ideas in order to 
research about the study or the discussion. This helps a lot in dealing easily and quickly with solving the problems and facing them, making decisions, and thinking creatively.

\section{Types of fluency:}

- Verbal fluency or word fluency: is the ability of an individual to produce the largest possible number of words that have specific characteristics (Al-Huwaidi, 2004: 27).

- Fluency of meanings, or intellectual fluency: is the ability to give the largest number of ideas in a specific time regardless of the type or level of these ideas, or aspects of experience in them (Al-Slaiti, 2006: 43).

- Fluency of shapes: It is the ability to change shapes with simple additions, and the ability to quickly draw a number of examples, details or adjustments in response to a particular visual stimulus. (AbuZayd, 1995: 165)

- Impact fluency: is the ability to produce the largest possible number of words which have one meaning, such as wars, battles, fighting, and armed conflict. This performance achieves relaxation for the student, activates memory and activates the mental organization processes in which this process is practiced. (His Excellency, 2003: 275)

- Expressive fluency: is the ability to give an expressive image and formulation of ideas in words so that there is a link between them which makes them appropriate for each other. The formulation of ideas should be fast and sound. (Abu Gado, 2004: 45)

\section{Flexibility}

- Definition: Melhem (2001: 238) thinks that it is the ability to generate various ideas and not usually expected thoughts, while directing the course of 
thinking according to the change of stimulus or the requirements of the situation.

- The importance of developing flexibility skill: when finishing the activities and required readings about flexibility skill, the student will be able to raise the number of the patterns of responses proposed. s/he also will be able to look at what beyond solving the problem proposed for discussion. $\mathrm{s} / \mathrm{he}$ will be able to apply the steps of flexibility skill and to judge the degree of effectiveness (Khader, 2011: 499).

- Types of flexibility: theoretical writings refer to two main types of flexibility as follows:

- Automatic resilience: means the speed in producing appropriate responses to a problem, or an exciting situation. the response is characterized by diversity and atypicality. It does not belong to one direction. Also, it is an ability or a skill that produces the largest number of ideas freely, and automatically away from the means of pressure or directing (Moses, 2000: 7-23).

- Adaptive flexibility: refers to the individual's ability to change the mental direction quickly in order to face changing problems. Thus, it reflects mental adaptation. A flexible person adapts the situations, and circumstances reflect a person who is mentally rigid towards attitudes and problems. (Camel, 2005: 50)

\section{Originality}

- Definition: Guilford defines it as (uncommon production), while Nofal (2009: 54) defines it as (the ability to express or generate new, unique and creative ideas). 
- The importance of originality skill:The importance of this skill as summed up by Al-Assaf (2013, 274), Khadr (2011: 499), and Qatami and Adas (2002: 55) is the necessity of students to think in an authentic way that helps them in search for new ideas. if the student is able to understand or absorb things in depth and authenticity, this leads to find other original ideas. The individual's thinking is described as original when his/her ideas are not repeated in others' work or in the groups' work to which he belongs.

\section{Definition of six-hat strategy}

De-Bono has divided human thinking into six forms. Every form has a specific hat worn or taken off by a person based on his/her way of thinking during that moment. He chooses the colors to distinguish the sixhats. The colors are chosen in a way that corresponds the nature and the type of thinking for every hat (DeBono, 2013: 47).

\section{Thinking implications for every hat}

- White hat: (information- data- requirements). AlJawsi (2001: 33) states that white hat stands for neutral thinking and objectivity. We ask some questions like: what are the questions that you want to ask? It sheds the light of the information available and unavailable. The one who wears the white has will be able to:

- Introduce direct and specific responses

- Care about the reality, numbers, statistics

- Imitate the computer's role in giving or receiving information (objectivity) 
- Strip form emotions and opinions

- Red hat (emotions- feelings): Al-Harthi (2003: 76) states that this hat is based on deep feelings, emotions, intuition, and guessing. The one who wears this hat is able to:

- Show his/her feelings and emotions with or without a reason

- Care about the emotions, not facts

- Tends to care about the humanistic or emotional part. His/her opinions and thinking are based on emotions, not logic. s/he neglects facts without a reasonable explanation. Emotions like fear, hatred, and anger affect his/her thinking.

- Black hat ( caution, Risks, difficulties, and negatives): Obaidat and Abu Al-Semid, (2005: 54), De Bono (2001: 84-262), and Dymer (2004: 30) explain that this hat is for pessimism, caution, fear, criticism, and thinking of risks. The one who wears this hat is able to:

- Be pessimistic, and has no optimicism about the possibility of success

- Always criticize performance

- Focus on the failed experiences and blocks.

- Yellow hat (the benefits, positives): Obeidat and Abu Al-Semid (2005: 54) state that this hat is for optimism and thinking of the benefits of the topic under discussion. The one who wears this hat is able to:

- Be optimistic

- Focus on the possibilities of success and reduce the possibility of failure 
- Not use the emotions clearly. Instead, s/he uses logic in a positive way and sizes the opportunities available.

- Green hat (new ideas): Al-Husseini (2012: 24) clarifies that this hat stands for creative thinking since the green color symbolizes creativity and innovation. It represents the growth of the plant. It means getting new ideas from old ones. This hat is one of the most difficult ones because creativity is a hard process and requires high skill level. The one who wears this hat is able to:

- Care about everything new (ideas, experiences, concepts,,, ect)

- Be ready to take risks and their consequences. s/he always seeks to develop and work for change and gives time and effort to search for new ideas and alternatives.

- Use creative ways (what, if, how, may be)

- Try to develop new and strange ideas

- Note: when the green hat is used, it should be followed by the black hat, then the yellow hat.

- Blue hat (holistic thinking): Al-Husseini (2012: 24), Babiker (2001: 54), and Al-Hammadi (1999: 32) states that this hat stands for holistic thinking. It is the general view thinking. It is a thinking of thinking. This type of thinking is considered to be the guide who directs the five types of thinking mentioned above. The one who wears this hat tries to summarize the discussion and specify the main point to each it.

\section{Ways of using thinking hats}

Salim (2013: 192-193), and Azayda (2017: 44-45) summarize the ways of using six-hat strategy as follows: 
- Individual use: means suing these hats individually in order to train the students to use them reasonably in certain situations. For example, red hat helps to move thinking into emotions and feeling when taking decisions, while yellow hat reveals positives. White hat helps collect facts and information needed to the educational situation, but the blue hat summarizes the outcomes and organizes them inside the learners' minds.

- Serial use: means to specify the sequence of the hat, then, moving from one hat into another in order to discover the topic completely during a short period of time. However, every topic is used when it is necessary. Every educational situation has a special sequence of hats.

\section{Benefits of using six hats strategy}

- Force: the person uses his/her intelligence and experience and previous knowledge. s/he uses his/her full potentials during discussions. Thus, persons' concentration is on the problem and the way of solving it.

- It leads to build effective ways of work

- Save time: thinking in this way at least saves half of the time compared with the traditional way. Thus, it reduces the money needed and rises the productivity.

- Easy to be applied in all levels

- Changes the negative situations into positive ones.

- Helps gain more time and efforts.

The two researchers her will prepare the lessons in English language course in a way that suits the subject and the way of representation. 
- They starts with the white hat. It reflects the objective thinking which cares about facts and numbers without explaining them. It also cares about collecting information and numbers neutrally and objectively.

- Then, they use red hat which reflects feelings and emotions without caring about logic, giving justifications, or discovering positives and negatives.

- After that, they use the yellow hat which reflects the positive thinking and determines the benefits and positives based on the data and information collected to give suggestions.

- Then, they introduce the green hat which leads to creative thinking throughout suggesting alternatives and introducing new solutions.

- Finally, they use the blue hat to control the process of organizing thinking and evaluating the previous hats. This hat controls the rest hats. They may reuse another had if it is necessary.

The relations between six-hat strategy and creative thinking

Form what is discussed above, six-hat strategy is based on thinking. It becomes crystal clear that teaching creative thinking has become a major goal for most of the educational policies in the world. In addition, it has become a goal that curriculum aim to achieve through the content because students face many difficulties in their life that need creative solutions. From this, the person has become in a critical need to learn creative thinking to face life problems. The modern education seeks to teach the students creative thinking skills, practice, and apply them to build his/ her personality 
every well. The student through using six-hat strategy thinks and deals with one thing at a specific period of time. s/he also is able to change his/her thinking based on the situation. Thus, the student will become more productive. Moreover, learning creative thinking skills, the student can feel that s/he has control over his/her thinking. Thus, his/her self confidence increases (Sauada, 2014: 263).

\section{English language material in primary school}

The recent years has witnessed a remarkable development in all fields of life because the world is experiencing huge changes and developments in science and technology. As a result of these changes in education and its applications, those in charge with the curriculum in general and English language material in particular should work hard to connect it with the real life by researching for new ways of teaching that motivate the students and create the oppotunties needed to make them interact positively with the different life situations. Thus, the material is enriched and has a social value. What the students learn is not far from the life aspects (Abdel Fattah, 2008: 5).

The importance of English language as a science and academic subject

- Teaching English helps transform the society's culture and helps the students choose the social and educational roles.

- Raising the students' feeling of belonging to a society. The cognitive education transforms what is known as the cultural heritage of the students. It helps increasing the new knowledge. Education sharpens 
the abilities of the individuals and contributes a lot in achieving the self (Shoman, 2010: 63-65).

- English language helps us explain and criticize the social patters that form the society. It provides us with information that can be used to direct the social policies.

- English language helps us know the traditions of the society, comparing them with traditions of other societies. It also clarifies the reasons behind forming these traditions, thus, revealing some facts about the society's life.

The educational importance of English language material in the primary school

The English language is considered one of the most important subjects that touches the lives of students in the basic stage since it deals with the social life in which the student lives in its various dimensions. It reports on problems such as population explosion, pollution, deviation and other social issues prevalent in society. (Faisal, 2010: 101-102).

\section{Second: previous studies}

First section: studies dealt with creative thinking Gerjovich (2000)

This study aims at revealing the relations between students' creativity by their creative thinking and the way they are taught at school in New Mexico state at USA. It concludes with the followings:

- There is a positive relation between developing creative thinking and the method of teaching used 
- There are statistically significant differences in the orientation towards the diversity of learning methods for more creativity and discovery in favor of females.

\section{Van Antwerp (2002)}

This study aims at identifying the effect of teacher's usage of methods of imagination and imaginary representation as a basic requirement for creative thinking on the students' achievements at primary schools. the study finds that there are statistically significant differences in favor of experimental group.

\section{Abd El-Aziz (2004)}

This study aims ar knowing the effects of using brainstorming strategy on teaching history on the historical recognition and developing creative thinking for first grade students at Egypt. The study finds that there is an indication between experiment group grads and controlled group grades in terms of fluency in favor of experimental group.

\section{Al-Kaltham (2005)}

The study aims at knowing the effect of teaching history on developing creative thinking for girl students at the third grade in literary stream by applying creative thinking program. The results show that there are statistically significant differences among controlled group grade and experimental group grade in their general ability go think creatively. The differences also are in one of the creative thinking tools, such as intellectual fluency, automatic flexibility, and originality in favor of experiemental group. 


\section{Al-Khada' (2005)}

The study aims at identifying the effectiveness of a proposed program to teach thinking skills for students of the second intermediate in Jordan in developing the skills of critical and creative thinking and achievement for Umayyad state unit in history subject. The results show that There is a statistical significance at the level of (0.50) among female students in developing creative thinking capabilities.

\section{Second section: studies dealt with six-hat strategy}

\section{Combe (1997)}

The study aims at identifying the impact of basic school students' education in New Zealand using the Six Thinking Hats strategy and the Kurt program on developing creative thinking. The study finds that there is a statistical significance between the degrees of students of the experimental group and the controlled group regarding the level of the ability to creative thinking in favor of experimental group.

\section{Awdat (2006)}

The study aims at revealing the effect of using brainstorming methods, the six hats, and the active lecture on achievement and contemplative thinking among students of the Mediterranean in the subject of national education in Jordan. The study finds that there is a statistical significance in the average achievement of students of the achievements' average in the subject of national education course among the group studied using six hats method and active lecture in favor of the group where six hats used. 


\section{Al-Subaie (2006)}

The study aims at preparing a training program based on six thinking hats for Bono and measuring its impact on developing leadership behavior among the primary stage students in the State of Kuwait. The study finds that there is a statistical significance between the experimental and controlled groups in favor of the experimental group.

\section{Essa (2009)}

The study aims at identifying the effect of the Six Hats strategy on expressive performance and post-cognitive skills among middle school students. The results finds that the experimental group gets higher results using Six Hats strategy compared with the control group using the traditional method.

\section{Asfour (2010)}

The study aims at getting a general view about the use of the Six Thinking Hats method in avoiding thinking errors and developing the decision-making skill of the third primary students in the subject of sociology. The results conforms the effectiveness of the six thinking hats in avoiding thinking errors and developing decision-making skill.

\section{Al-Khazraji (2010)}

The study aims at identifying the effect of the Six Hats strategy on achievement among middle school students in history. The study finds that there are statistically significant differences between the experimental group where the Six Hats strategy is applied and the control group that studied the same subject in the usual way in favor of the experimental group. 


\section{The study experimental design}

The researchers follow the experimental approach in which they make two independent groups. Then, they carry out a pre-test targeting the two groups: experimental group and the controlled group. After that, they teach the subject using six-hat strategy. Finally, they conduct a post text on the two groups. They calculate the results statistically. The following table clarifies that:

Table 1: clarifying the study form

\begin{tabular}{|c|c|c|c|}
\hline group & $\begin{array}{c}\text { Pre-test for creative } \\
\text { thinking }\end{array}$ & $\begin{array}{c}\text { Six } \\
\text { hats }\end{array}$ & $\begin{array}{l}\text { Post text for creative } \\
\text { thinking }\end{array}$ \\
\hline Controlled group & $T$ & $\mathbf{F}$ & $T$ \\
\hline $\begin{array}{l}\text { Experimental } \\
\text { group }\end{array}$ & $T$ & $\mathbf{T}$ & $\mathbf{T}$ \\
\hline
\end{tabular}

\section{Choosing the study sample}

The study sample is chosen from the fourth grade students who are studying in the second semester in 2019-2020. The researchers rely on a standard test for creative thinking with its dimensions: fluency, flexibility, and originality. The sample size is 80 students from Beuit Lahya primary school. The sample is divided into two groups:

- Experimental group includes 40 students. And the six-hat strategy is applied to this group.

- Controlled group includes 40 students and the six-hat strategy is not applied here.

Table 2: clarifying the study sample

\begin{tabular}{|c|c|c|}
\hline Group & Students number & Class \\
\hline Experimental group & $\mathbf{4 0}$ & Fourth 3 \\
\hline Controlled group & $\mathbf{4 0}$ & Fourth 2 \\
\hline
\end{tabular}

\section{Applying the pre-test}

A pre-test is carried out on the two groups in order to know the creative thinking level among the students 
and ensure that the two groups are homogenous. These things are taken into consideration:

- Explaining the instructions included

- No interference while students are solving

- the two groups have the same test

- the pre-test is carried out with the same circumstances in the two groups.

\section{Calculating the homogeneity of the two groups:}

- homogeneity of the two groups throughout carrying creative thinking test

- homogeneity of the average results of the controlled and experimental groups

To ensure the homogeneity of the two groups, the researchers ensure that there is no statistically significant difference among the average results of the experimental and controlled groups before applying six-hat strategy. for more clarification, see table 3:

Table 3: Clarifying the differences among the average results of the experimental and controlled groups in applying the pre-test of creative thinking

\begin{tabular}{|c|c|c|c|c|c|c|c|c|}
\hline & group & No & Average & $\begin{array}{l}\text { standard } \\
\text { deviation }\end{array}$ & $\begin{array}{c}\mathbf{T} \\
\text { value }\end{array}$ & \begin{tabular}{|c|}
$\begin{array}{c}\text { Significance } \\
\text { level }\end{array}$ \\
\end{tabular} & sig & Degree \\
\hline \multirow{2}{*}{ Fluency } & Experimental & 40 & 7.38 & 2.11 & \multirow{2}{*}{0.335} & \multirow{2}{*}{0.05} & \multirow{2}{*}{0.739} & \multirow{2}{*}{58} \\
\hline & Controlled & 40 & 7.22 & 1.73 & & & & \\
\hline \multirow{2}{*}{ Flexibility } & Experimental & 40 & 7.67 & 0.987 & \multirow{2}{*}{0.135} & \multirow{2}{*}{0.05} & \multirow{2}{*}{0.893} & \multirow[t]{2}{*}{58} \\
\hline & Controlled & 40 & 3.7 & 0.922 & & & & \\
\hline \multirow{2}{*}{ Originality } & Experimental & 40 & 3.03 & 0.921 & \multirow{2}{*}{0.875} & \multirow{2}{*}{0.05} & \multirow{2}{*}{0.385} & \multirow[t]{2}{*}{58} \\
\hline & Controlled & 40 & 3.27 & 1.07 & & & & \\
\hline \multirow{2}{*}{$\begin{array}{l}\text { The final } \\
\text { result }\end{array}$} & Experimental & 40 & 14.08 & 2.49 & \multirow{2}{*}{1.452} & \multirow{2}{*}{0.05} & \multirow{2}{*}{0.152} & \multirow[t]{2}{*}{58} \\
\hline & Controlled & 40 & 15.16 & 2.48 & & & & \\
\hline
\end{tabular}

From the previous table, there are no statistically significant differences among average results of the two groups regarding skills and the final result for the pretest. 


\section{Homogeneity of the controlled group and the experimental one:}

To ensure the homogeneity of the two groups, the researchers ensure the homogeneity of the controlled group and the experimental group before applying sixhat strategy. the following table explains this:

Table 4: clarifies the value of $F$ among the results of controlled and experimental groups in the application of the creative thinking test

\begin{tabular}{|c|c|c|c|c|c|}
\hline & group & No & F value & $\begin{array}{c}\text { Significance } \\
\text { level }\end{array}$ & Sig \\
\hline \multirow{2}{*}{ Fluency } & Experimental & 40 & \multirow{2}{*}{1.11} & \multirow{2}{*}{0.05} & \multirow{2}{*}{0.297} \\
\hline & Controlled & 40 & & & \\
\hline \multirow{2}{*}{ Flexibility } & Experimental & 40 & \multirow{2}{*}{0.192} & \multirow{2}{*}{0.05} & \multirow{2}{*}{0.663} \\
\hline & Controlled & 40 & & & \\
\hline \multirow{2}{*}{ Originality } & Experimental & 40 & \multirow{2}{*}{0.227} & \multirow{2}{*}{0.05} & \multirow{2}{*}{0.635} \\
\hline & Controlled & 40 & & & \\
\hline \multirow{2}{*}{ The final results } & Experimental & 40 & \multirow{2}{*}{0.214} & \multirow{2}{*}{0.05} & \multirow{2}{*}{0.645} \\
\hline & Controlled & 40 & & & \\
\hline
\end{tabular}

From the table above, $\mathrm{F}$ value on the significance level 0.05 , there are not statistically significant differences among the controlled and experimental groups in terms of the skills, the final results, and the application of the pre-test for creative thinking. Thus, the two groups are homogenous.

\section{The contest of the experimental treatment}

The researcher teach the experimental group students using six-hat strategy. To attract the students' attentions of the subject matter of the research, they conduct an opening session to get to know the students, and to introduce the study aims, and the application. After that, every lesson is distributed to be explained at the beginning of every class. Also, the second semester subjects are taught during $1 / 2 / 2020$ till 19/2/2020. 
The researchers explain the topics in 13 classes, in addition to a class for introducing the study aims. On the other hand, the teacher uses the traditional methods in the controlled group during the same period.

Table 5: the number of classes

\begin{tabular}{|c|c|}
\hline The class aim & Class number \\
\hline Applying the pre-test & 2 \\
\hline An opening class & 1 \\
\hline Teaching & 13 \\
\hline Post-test & 2 \\
\hline The overall no & 17 \\
\hline
\end{tabular}

\section{Applying the post test}

The same test is applied for the experimental group and controlled one at the end of the training period. After that, the results are written and processed statistically.

\section{First: statistical methods used}

After applying the post test which is a test to measure the creative thinking ability and the self-confidence measure for shroder, the test is corrected. The marks are changed into standard marks. Then, data are statistically processed to ensure the correctness of the hypotheses, revealing the effectiveness degree of sixhat of De Bono to develop creative thinking and self confidence. To process these data, the following statistical methods are used:

paired samples test

SPSS version 17 is used to analyze data obtained to calculate the difference between the marks average between the pre and post tests. Thus, the effectiveness of six-hat strategy in teaching English and developing creative thinking skills is revealed. 
calculating the effect degree to know the effectiveness of statistical processes.

To calculate the effect degree the value of Ita square is calculated to know the differences in variance in the degrees of the dependent variable, which is due to the independent variable

\section{Second: presenting, discussing, and interpreting the results of the qualitative analysis}

presenting and discussing the results connected with the first hypothesis

to check the correctness of the first hypothesis which states: " There are statistically significant differences at the level (0.05) between the average scores of students of the experimental and control groups in the postapplication of the creative thinking test in favor of the experimental group, the results are clarified in the following table:

table (6): the significance of differences between the average results of the two groups in post test application for creative thinking

\begin{tabular}{|c|c|c|c|c|c|c|c|c|}
\hline & group & No & Average & $\begin{array}{l}\text { standard } \\
\text { deviation }\end{array}$ & T value & $\begin{array}{c}\text { Significance } \\
\text { level }\end{array}$ & Sig & Degree \\
\hline \multirow{2}{*}{ Fluency } & Experimental & 40 & 7.48 & 1.94 & \multirow{2}{*}{6.12} & \multirow{2}{*}{0.05} & \multirow{2}{*}{0.000} & \multirow{2}{*}{58} \\
\hline & Controlled & 40 & 10.35 & 1.67 & & & & \\
\hline \multirow{2}{*}{ Flexibility } & Experimental & 40 & 3.70 & 0.92 & \multirow{2}{*}{6.66} & \multirow{2}{*}{0.05} & \multirow{2}{*}{0.000} & \multirow{2}{*}{58} \\
\hline & Controlled & 40 & 5.63 & 1.30 & & & & \\
\hline \multirow{2}{*}{ Originality } & Experimental & 40 & 333.40 & 0.99 & \multirow{2}{*}{7.60} & \multirow{2}{*}{0.05} & \multirow{2}{*}{0.000} & \multirow{2}{*}{58} \\
\hline & Controlled & 40 & 4.93 & 0.94 & & & & \\
\hline \multirow{2}{*}{$\begin{array}{l}\text { The final } \\
\text { result }\end{array}$} & Experimental & 40 & 14.22 & 2.36 & \multirow{2}{*}{9.21} & \multirow{2}{*}{0.05} & \multirow{2}{*}{0.000} & \multirow{2}{*}{58} \\
\hline & Controlled & 40 & 20.92 & 3.21 & & & & \\
\hline
\end{tabular}

Form the table above, there are statistically significant differences at 0.05 level among the average marks in post test application for creative thinking in favor of experimental group. This approves that there is a 
noticeable development in the final results of the Torance test for creative thinking in the experimental group due to the use of six-hat strategy.

presenting and discussing the results of the second hypothesis

To check to correctness of the second hypothesis which states that"There are statistically significant differences at the level (0.05) between the average scores of the experimental group students in the pre and post application in favor of post-application in the postcreative thinking test in favor of post-application, the results are clarified in the following table:

Table 7: the difference between the average marks of the pre and post tests in the major skills: fluency, flexibility, and originality for creative thinking test

\begin{tabular}{|c|c|c|c|c|c|c|c|c|}
\hline & application & No & Average & $\begin{array}{l}\text { standard } \\
\text { deviation }\end{array}$ & $\begin{array}{c}F \\
\text { value }\end{array}$ & $\begin{array}{c}\text { Significanc } \\
\text { e level }\end{array}$ & Sig & $\begin{array}{c}\text { Effect } \\
\text { size }\end{array}$ \\
\hline \multirow{2}{*}{ Fluency } & Pre & 40 & 7.22 & 1.73 & \multirow{2}{*}{6.71} & \multirow{2}{*}{0.05} & \multirow{2}{*}{0.000} & \multirow{2}{*}{0.38} \\
\hline & Post & 40 & 10.35 & 1.73 & & & & \\
\hline \multirow{2}{*}{ Flexibility } & Pre & 40 & 3.70 & 0.98 & \multirow{2}{*}{6.38} & \multirow{2}{*}{0.05} & \multirow{2}{*}{0.000} & \multirow{2}{*}{0.14} \\
\hline & Post & 40 & 5.63 & 1.43 & & & & \\
\hline \multirow{2}{*}{ Originality } & Pre & 40 & 3.27 & 1.07 & \multirow{2}{*}{7.76} & \multirow{2}{*}{0.05} & \multirow{2}{*}{0.000} & \multirow{2}{*}{0.39} \\
\hline & Post & 40 & 4.93 & 0.94 & & & & \\
\hline $\begin{array}{l}\text { The final } \\
\text { result }\end{array}$ & Pre & 40 & 14.18 & 2.48 & 8.12 & 0.05 & 0.000 & 0.36 \\
\hline
\end{tabular}

As shown the this table, there are statistically significant differences at level (0.05) among the average marks of the students in the pre and post tests for creative thinking test in favor of the post application. This proves that there is a kind of development in the final results to check the ability of creative thinking for the experimental group due to the experimental processes used (six-hat strategy). 
presenting and discussing the results of the third hypothesis to check correctness of the third hypothesis which states that"There are statistically significant differences at the level (0.05) between the average scores of students of the experimental group in the pre and post application in the skill of fluency in favor of post application", the results are summarized in the following table:

table (8): the differences between the average results of the pre and post applications in the sub skills to fluency for creative thinking

\begin{tabular}{|c|c|c|c|c|c|c|c|c|}
\hline & Application & No & Average & $\begin{array}{l}\text { standard } \\
\text { deviation }\end{array}$ & $\begin{array}{c}T \\
\text { value }\end{array}$ & $\begin{array}{c}\text { Significanc } \\
\text { e level }\end{array}$ & Sig & $\begin{array}{c}\text { Effect } \\
\text { size }\end{array}$ \\
\hline \multirow{2}{*}{$\begin{array}{l}\text { Verbal } \\
\text { Fluency }\end{array}$} & Pre & 40 & 3.03 & 1.13 & \multirow{2}{*}{5.58} & \multirow{2}{*}{0.05} & \multirow{2}{*}{0.000} & \multirow{2}{*}{0.47} \\
\hline & Post & 40 & 4.76 & 1.38 & & & & \\
\hline \multirow{2}{*}{$\begin{array}{l}\text { Expressive } \\
\text { fluency }\end{array}$} & Pre & 40 & 2.03 & 0.67 & \multirow{2}{*}{4.40} & \multirow{2}{*}{0.05} & \multirow{2}{*}{0.000} & \multirow{2}{*}{0.18} \\
\hline & Post & 40 & 3.43 & 0.57 & & & & \\
\hline \multirow{2}{*}{$\begin{array}{l}\text { Intellectual } \\
\text { fluency }\end{array}$} & Pre & 40 & 2.15 & 0.76 & \multirow{2}{*}{5.30} & \multirow{2}{*}{0.05} & \multirow{2}{*}{0.000} & \multirow{2}{*}{0.27} \\
\hline & Post & 40 & 3.15 & 0.71 & & & & \\
\hline \begin{tabular}{|l|} 
The final \\
result
\end{tabular} & Pre & 40 & 7.22 & 1.73 & 6.71 & 0.05 & 0.000 & 0.39 \\
\hline
\end{tabular}

As shown in the previous table:

There are statistically significant differences at level (0.05) among average marks of post application for creative thinking test in terms of fluency skill in favor of experimental group. This approves that there is a kind of development in the final results of the creative thinking test of the experimental group due to the experimental processes used (six-hat strategy).

presenting and discussing the results of the fourth hypothesis

To check the correctness of the fourth hypothesis which states that:"There are statistically significant differences at the level (0.05) between the average scores of the experimental group students in the pre and post application in the skill of originality in favor of post application. The results as shown in the following table: 
Table (9): the differences between average marks among the pre and post tests in the sub skills of originality for creative thinking test

\begin{tabular}{|l|c|c|c|c|c|c|c|c|}
\hline & application & No & Average & $\begin{array}{c}\text { standard } \\
\text { deviation }\end{array}$ & $\begin{array}{c}\text { T } \\
\text { value }\end{array}$ & $\begin{array}{c}\text { Significance } \\
\text { level }\end{array}$ & Sig & $\begin{array}{r}\text { Effect } \\
\text { size }\end{array}$ \\
\hline \multirow{2}{*}{ Originality } & Pre & 40 & 3.26 & 1.07 & \multirow{2}{*}{7.76} & 0.05 & 0.000 & 0.39 \\
\cline { 2 - 8 } & Post & 40 & 4.93 & 0.94 & 0.39 & 0.05 \\
\hline
\end{tabular}

As shown in the previous table:

There are statistically significant differences at level (0.05) among average marks of post application for creative thinking test in terms of originality skill in favor of experimental group. This approves that there is a kind of development in the final results of the creative thinking test of the experimental group due to the experimental processes used (six-hat strategy).

presenting and discussing the results of the fifth hypothesis To check the correctness of the fifth hypothesis which states that: There are statistically significant differences at the level $(0.05)$ between the average scores of the experimental group students in the pre and post application in the skill of flexibility in favor of the post application". The results as shown in the following table:

Table (10): differences among average results of the pre and post tests in sub skills of flexibility for creative thinking test:

\begin{tabular}{|c|c|c|c|c|c|c|c|c|}
\hline & Application & No & Average & $\begin{array}{l}\text { standard } \\
\text { deviation }\end{array}$ & T value & $\begin{array}{c}\text { Significance } \\
\text { level }\end{array}$ & Sig & \begin{tabular}{|l|}
$\begin{array}{l}\text { Effect } \\
\text { size }\end{array}$ \\
\end{tabular} \\
\hline \multirow{2}{*}{$\begin{array}{l}\text { Automatic } \\
\text { flexibility }\end{array}$} & Pre & 40 & 2.07 & 0.69 & \multirow{2}{*}{6.07} & \multirow{2}{*}{0.05} & \multirow{2}{*}{0.000} & \multirow{2}{*}{0.24} \\
\hline & Post & 40 & 3.23 & 0.73 & & & & \\
\hline \multirow{2}{*}{$\begin{array}{l}\text { Adaptive } \\
\text { flexibility }\end{array}$} & Pre & 40 & 1.63 & 0.72 & \multirow{2}{*}{4.04} & \multirow{2}{*}{0.05} & \multirow{2}{*}{0.000} & \multirow{2}{*}{0.15} \\
\hline & Post & 40 & 2.40 & 0.77 & & & & \\
\hline \multirow{2}{*}{$\begin{array}{l}\text { Final } \\
\text { results }\end{array}$} & Pre & 40 & 3.70 & 0.98 & \multirow{2}{*}{6.38} & \multirow{2}{*}{0.05} & \multirow{2}{*}{0.000} & \multirow{2}{*}{0.20} \\
\hline & Post & 40 & 5.63 & 1.30 & & & & \\
\hline
\end{tabular}

As shown in the previous table:

There are statistically significant differences at level (0.05) among average marks of post application for creative thinking test in terms of flexibility skill in favor 
of experimental group. This approves that there is a kind of development in the final results of the creative thinking test of the experimental group due to the experimental processes used (six-hat strategy).

presenting and discussing the results of the sixth hypothesis To check the correctness of the fifth hypothesis which states that: There are statistically significant differences at the level (0.05) between the average scores of the experimental group students in the pre and post application in self confidence level in favor of the post application". The results as shown in the following table:

Table (11): differences among average results of the pre and post tests in self confidence scale

\begin{tabular}{|c|c|c|c|c|c|c|c|c|c|}
\hline$\square$ & $\square$ & Application & No & average & $\begin{array}{l}\text { standard } \\
\text { deviation }\end{array}$ & \begin{tabular}{|c|}
$T$ \\
value \\
\end{tabular} & $\begin{array}{c}\text { Significance } \\
\text { level }\end{array}$ & sig & $\begin{array}{l}\text { Effect } \\
\text { size }\end{array}$ \\
\hline \multirow{4}{*}{$\begin{array}{l}\text { Positive } \\
\text { statements }\end{array}$} & \multirow{2}{*}{ Controlled } & Pre $\square$ & 40 & 1.75 & 0.73 & \multirow{2}{*}{1.63} & \multirow{2}{*}{0.05} & \multirow{2}{*}{0.184} & \multirow{2}{*}{0} \\
\hline & & Post & 40 & 1.74 & 0.73 & & & & \\
\hline & \multirow{2}{*}{ Experimental } & Pre $\square$ & 40 & 2.74 & 0.71 & \multirow{2}{*}{10.55} & \multirow{2}{*}{0.05} & \multirow{2}{*}{0.000} & \multirow{2}{*}{0.994} \\
\hline & & Post & $40 \square$ & 1.78 & 0.75 & & & & \\
\hline \multirow{4}{*}{$\begin{array}{l}\text { Negative } \\
\text { statement } \\
\text { s }\end{array}$} & \multirow{2}{*}{ Controlled } & Pre & 40[ & 1.74 & 0.39 & \multirow{2}{*}{1.68} & \multirow{2}{*}{0.05} & \multirow{2}{*}{0.103} & \multirow{2}{*}{0} \\
\hline & & Post & 40[ & 1.73 & 0.39 & & & & \\
\hline & \multirow{2}{*}{ Experimentall } & Pre & 40[ & 1.81 & 0.58 & \multirow{2}{*}{11.75} & \multirow{2}{*}{0.05} & \multirow{2}{*}{0.000} & \multirow{2}{*}{0.865} \\
\hline & & Post & 40[ & 2.76 & 0.38 & & & & \\
\hline
\end{tabular}

As shown in the previous table:

There are statistically significant differences at level (0.05) among average marks after applying self confidence scale, while there are not statistically significant differences in the controlled group. This approves that there is a kind of development in the effect resulted from application regarding applying self confidence scale on experimental group.

\section{Recommendations}

In light of the results of the study, the following recommendations can be presented: 
- Encouraging teachers to employ and use De Bono technique in all academic subjects that help develop creative thinking and its skills among students of the primary stage.

- The necessity of putting inside primary schools textbooks some creative thinking skills, such as fluency, flexibility and originality.

- The necessity for English teachers to use teaching strategies that depend on the learner's activity by working in small groups.

- caring of using modern strategies that help develop creative thinking skills so that students become aware of their thinking and are responsible for their learning processes.

\section{References}

- Abu-Jado, S. (2004). Practical applications developing creative thinking using creative solution theory for problems. Jordan: AlShorog publication house.

- Abu-Zid, A. (1995). Creativity phenomenon. Thinking world, 15(4). 34-44.

- Azayda, R. (2017). Six-hat program (activities and practical applications). Amman: Debono Center

- Al-Jamal, M. (2005). Developing creative thinking skills through curriculum. UAE: university student book house.

- Jawad, W. (2010). Establishing the ability of verbal creative thinking test for Baghdad

- university students. Educational and physiological research journal, (26- 27),

- Educational and Psychological Research Center, 208-230.

- Habash, Z. (2002). Educational horizons in teaching, learning and creativity.

- Ramallah: Al-'nga Foundation for Innovation and Creativity.

- Al-Harthi, I. (2003). Teaching thinking. Riyadh: King Fahd National Library..

- Al-Hussaini, F. (2012). Effectiveness of teaching geography of the Arab world to tenth grade students in the State of Kuwait using the six hats and their effect on their achievement and critical thinking 
(unpublished Master Thesis), College of Educational Sciences, Middle East University

- Al-Hussaini, F. (2012). Effectiveness of teaching geography of the Arab world to tenth grade students in the State of Kuwait using the six hats and their effect on their achievement and critical thinking (unpublished Master Thesis), College of Educational Sciences, Middle East University

- Al-Hammadi, A. (1999). The way of generating creative ideas. Beirut: Dar Bin Hazm for Printing. Publishing and Distribution.

- Khazraji, M. (2011). The effect of the Six Hats strategy on achievement among middle school students in the subject of history. (unpublished Master Thesis), College of Education, Diyala University.

- Al-Khidr, Tohme, Siyam, and Waheed. (2013). Development of creativity skills. Damascus: Dar Al-Quds Science for Printing, Publishing and Distribution.

- Khader and Tohme. (2014). Development of thinking skills (2). Damascus: Dar Al Quds Science for Printing, Publishing, and Distribution.

- Khidr and Najwa (2011). The effect of a program based on some scientific activities on developing creative thinking skills for a kindergarten child. Damascu University Journal, 27 (499), 122-137

- Al-Khadra and Fadia (2005). Developing Critical and Innovative Thinking "An Empirical Study" (published Master Thesis). Debono for Printing, Publishing, and Distribution, University of Amman, Jordan

- Al-Khatib and Raed (1995). The impact of a training program for cognition, interaction, information, and sensitivity skills on the development of creative thinking among the ninth grade students (unpublished master's thesis). University of Jordan, Amman, Jordan.

- De Bono, E. (2001). Six Thinking Hats, translated by: Khalil AlJayoushi. Abu Dhabi, The Cultural Society for Publishing and Distribution

- --. (2001). Kurt Thinking Education Program: Expanding the Realm of Realization, translation: Nadia Sorour and others. Amman: Dar Al-Fikr.

(2001). Teaching Thinking, translation: Adel AbdulKarim and others. Damascus: Dar Al-Reda

(2013). The Six Thinking Hats, translated by Sherif Mohsen, Edition (8). Egyptian Renaissance House. 
- Al-Deeb, I. (2005). The foundations and skills of creativity and innovation and its applications in the education system. Mansoura: Umm Al-Qura Foundation for Distribution.

- Rashtieh and Dirar. (2002). Using creative thinking skills in teaching Arabic language for sixth graders in Nablus Governorate and its effect on achievement and solving language problems (Unpublished Master Thesis). An-Najah National University, Nablus, Palestine.

- Robert Sternberg. (2005). A Reference in Creativity and Psychology, translation: Mohamed Naguib El-Sabwa, et al., Cairo: The Supreme Council of Culture.

- Zaytoon, A. (1987). Development of creativity and reflection in teaching of science. Amman: Oman Society for Cooperative Printing.

\section{Shorouk for Publishing and Distribution.}

(2001). Methods of Teaching Sciences. Oman: Dar Al-

- Al-Subaie and Mayouf. (2006). Building a teaching program based on six thinking hats by Bono and measuring its effect in developing leadership behavior among high school students in the State of Kuwait (published doctoral thesis). Amman Arab University for Graduate Studies, Jordan.

- Al-Surur, N. (2002). Using creative thinking skills in teaching Arabic language for sixth graders in Nablus Governorate and its effect on their achievement in solving language problems (published Master Thesis), College of Graduate Studies, An-Najah National University.

- Al-Surur, Nadia (2002). An introduction to creativity. Amman: Wael Publishing House.

- Saadeh, J. (2014). Teaching thinking skills "with practical examples". Amman: Jordan, Dar Al-Shorouk for Publishing and Distribution

- Saadeh, J and Qatami, Y. (1996). The ability of creative thinking among students of Qaboos University. series of psychological and educational studies issued by Qaboos University, 1.12-53

- Su'ad and et al. (1996). The effect of the education level for father and mother learning and congenital training on creative thinking abilities among a sample of preschool children in the State of Bahrain. Journal of Educational Research Center, Fifth Year, (9), 135-177

- Su'ad, J. (2003). Teaching thinking skills. An-Najah National University, Nablus: Dar Al-Shorouk. 
- Al-Celiti, F. (2006). Critical and creative thinking collaborative learning strategy in teaching reading and texts. Oman: Modern book world.

- Salim, Abu Hashem Abdel Aziz. (2013). The effectiveness of using Six Thinking Hats strategy in developing achievement and critical thinking among second - grade middle school students. Mathematics Education Journal, The Egyptian Mathematical Education Society, 6 (1), 192-193.

- Shoman, I. (2010). Principles of Sociology. University of Dammam, distance education for publication and distribution.

- Abdulaziz, Al-Saeed. (2004). The effect of using brainstorming strategy in teaching history on historical understanding and developing creative thinking among first-year high school students. Journal of the Faculty of Education, Benha University, 10-29.

- Abdel-Fattah, A. (2008). Effectiveness of a proposed program using cognitive and metacognitive strategies in social issues to develop awareness and critical thinking among teachers' students (unpublished doctoral dissertation). Department of Philosophy and Sociology, Faculty of Education, Fayoum University.

- Abdul Hadi, N and et al. (2003). Language and Thinking Skills. Jordan: Al Masirah House for Publishing, Distribution, and Printing.

- Obaid, W and Afana, I. (2003). Thinking and school curriculum. AlAin: Al-Falah Library for Publishing and Distribution.

- Obaidat, T, and Abu Samid, S. (2005). Teaching Strategies in the Twenty-first Century: Teacher's Guide and Educational Supervisor. Amman: Debono Publishing.

- Al-Assaf, J. (2013). Attitudes of social studies teachers towards developing creative thinking skills among students of the upper basic stage in Amman Education Directorate. Al Balqa University, Journal of the Islamic University for Educational and Psychological Studies, 21 (1), 269-292.

- Asfour, I. (2010). Using Six Thinking Hats method to avoid thinking errors and developing decision-making skills for third-year students in the subject of sociology. Journal of the Educational Association for Social Studies, Egypt, (30), 68-144.

- Ali, L. (2011). Creative thinking among managers and its relationship to solving administrative problems $\left(1^{\text {st }}\right.$ edition). Jordan: Al Yazouri Scientific House for Publishing and Distribution.

- Ali, M. (1999). The effectiveness of a proposed program in mathematical geography in developing innovative thinking and 
academic achievement among students in Faculty of Education, Department of Geography, Journal of Studies in Curricula and Teaching Methods, (59), 215-238.

- Omar, C. (2012). The effect of using brainstorming approach in developing creative thinking and achievement in geography for seventh students in the northern Gaza Strip (unpublished master's thesis). College of Education, Al-Azhar University, Gaza.

- Audat, H. (2006). The effect of using brainstorming methods, six hats, and active lecture on achievement and contemplative thinking among middle school students in the subject of national education in Jordan (unpublished doctoral thesis). University of Jordan, Amman, Jordan.

- Essa, Al-Saadi. (2009). The effect of six hats on expressive performance and post-cognitive skills among female teachers in teacher training institutes (unpublished doctoral dissertation), University of Baghdad, College of Education, Baghdad.

- Faisal, A. (2009). Sociology and development of social awareness of local and global variables. National Center for Educational Research and Development, Cairo: Modern Library for Publishing.

- Al-Qahtani, S. (2000). Organizational impediments to creativity. King Saud University Journal, Riyadh, 14 (2), 40-69.

- Katame, Naifeh (2001). Teaching thinking for the basic stage. Amman: Dar Al-Fikr for printing, publishing and distribution.

- Katame, N and et al. (2008). Creative Thinking. Amman: Publications of Al-Quds Open University.

- Qattami, Youssef and Adass, Abdel Rahman. (2002). General Psychology. Amman: Dar Al-Fikr for Publishing and Distribution.

- Qattami, Youssef and Al-Lawzi, Maryam. (2008). Creative Writing for talented students Model and Application. Jordan: Wael House for Printing, Publishing, and Distribution.

- Al-Madhoun, Hanan Khalil Muhammad (2012). The effect of using Six Thinking Hats program in developing creative thinking in human rights topic for sixth graders in Gaza (Published Master Thesis). College of Education, Al-Azhar University, Gaza.

- Al-Musharrafi, I. (2005). Family and Teacher Guide in Creative Education. Alexandria: Horus International Foundation for Publishing and Distribution.

(2011). Self-confidence and curiosity (status - trait) and

- achievement motivation among a sample of high school students in Makkah region and its relationship to some variables 
(unpublished PhD thesis). College of Education, Umm Al-Qura University.

- Al-Mefleh, Abdullah (2006). A course in developing thinking skills. Saudi Arabia: Dar Al-Shorouk.

- Melhem, S. (2001). Psychology of Learning and Teaching "Theoretical and Applied Foundations". Amman: Dar Al-Fikr for Publishing.

- Musa, M. (2000). The extent of contribution of educational and evaluation activities in the Arabic language books prescribed to the higher grades of the primary stage of the United Arab Emirates in developing creative thinking skills, Journal of Reading and Knowledge, (2), 180-186.

- Al-Nafi, Abdullah. (2008). Standardization of Torrance Standard for Creative Thinking and its Applications in the Saudi Environment. Fifth Administrative Forum for Creativity and Management Excellence, Saudi Arabia.

- Al-Naqa, Muhammad Kamil Hassan (2006). Criteria of Contemporary Originality of Quality for Educational Elements of Teaching Methods. International Islamic Education Institute, Sudan, April.

- Gitovner, D. (2000). Imagination Beats Knowledge Hands Down long is land Business News, 47 (42) 33- A.

- Starko, A. (2005).Creativity in the classroom Schools of Curious Delight. London. Lawrence Erlbaum Associates.

- Van. Antwerp, G.(2002). Fantasy and imagination as prereguisites for Creative thinking during foundation base Education (Unpublished master thesis). university of south Africa South Africe 